\title{
Evaluation of Potentially Toxic Elements in Mundaú Lagoon (Maceió, AL-Brazil): Systematic Environmental Monitoring of Water and Food Quality
}

\author{
Mayara C. dos Santos, ${ }^{a}$ Reginaldo C. da Silva Filho, ${ }^{a}$ Ana Catarina R. Leite, ${ }^{a}$ \\ Clésia C. Nascentes, ${ }^{b}$ Wander G. Botero ${ }^{a}$ and Josué C. C. Santos ${ }^{\circledR} * a$ \\ ${ }^{a}$ Instituto de Química e Biotecnologia, Universidade Federal de Alagoas (UFAL), \\ Campus A. C. Simões, 57072-900 Maceió-AL, Brazil \\ ${ }^{b}$ Departamento de Química, Universidade Federal de Minas Gerais (UFMG), \\ 31270-901 Belo Horizonte-MG, Brazil
}

\begin{abstract}
The Mundaú lagoon (Maceió, AL), besides being relevant socially, economically, and culturally, also in its surroundings, presents an intense anthropic occupation, characterized by a large population and the industrial activities presence. In this systematic environmental monitoring study (from 2017 to 2019), concentrations of Al, As, Bi, Cd, Cr, Cu, Fe, Hg, Li, Mn, Mo, Ni, Pb, Sb, Sn, $\mathrm{V}$, and $\mathrm{Zn}$ in surface waters, and total $\mathrm{Hg}$ content in the bivalve Mytella charruana (sururu) were recorded, using cold vapor atomic fluorescence spectrometry (or hydride generation) (HG/CV AFS), inductively coupled plasma mass spectrometry (ICP-MS), and chronopotentiometry. In the water samples, the following elements presented concentrations above the values recommended by the National Council for the Environment (CONAMA), in $\mu \mathrm{g} \mathrm{L}{ }^{-1}$ : Al (24.4-2008), Cu (1.88-13.03), Fe (84.9-4107), Hg (<0.0069-2.92), Mn (10.65-200), Pb (192-1443) and Zn (121-997), and therefore, the water was classified following the water pollution index (WPI), as highly impure and polluted. The $\mathrm{Hg}$ content in sururu, the main food in Mundaú lagoon, ranged from $0.036-0.63 \mathrm{mg} \mathrm{kg}^{-1}$ (dry weight). Further, the chemometric evaluation of the data based on the principal component and correlation analysis suggested a chemical-defined profile at the different sampling points.
\end{abstract}

Keywords: Mundaú lagoon, environmental monitoring, water quality, bivalve, potentially toxic elements

\section{Introduction}

The Mundaú-Manguaba estuarine lagoon complex (MMELC) in Alagoas (Brazil) supports 260 thousand inhabitants living in its surroundings and is considered one of the most important ecosystems in the State. The MMELC comprises Mundaú $\left(27 \mathrm{~km}^{2}\right)$ and Manguaba lagoons $\left(42 \mathrm{~km}^{2}\right)$, in the municipalities of Maceió, Rio Largo, Santa Luzia do Norte, Satuba, Coqueiro Seco, Marechal Deodoro, and Pilar. ${ }^{1}$

Mundaú lagoon (Maceió, AL) stands out for its accelerated processes of environmental degradation, which are due to various anthropic activities and a high population, the absence of basic sanitation and solid waste collection in various places, to silting, and its proximity to an industrial hub which includes sugar-alcohol activity. ${ }^{2}$

*e-mail: josue@iqb.ufal.br
The Mundaú River basin houses the MMELC, supplies Maceió, and other municipalities, irrigates sugar cane plantations, supplies water to the sugar-alcohol and petrochemical industries, and is also associated with tourism. Thus, especially for Mundaú lagoon, the study of environmental quality is essential due to the many purposes and applications using its waters. ${ }^{3}$ In 2019, according to the National Water Agency, in just one day, about $126 \mathrm{~m}^{3}$ of garbage (equivalent to 21 trucks) was removed from the Mundaú lagoon. Plastic bags, PET (polyethylene terephthalate) bottles, cans, tires, furniture, appliances (televisions and washing machines), and others, in addition to solid waste, was encountered. According to this agency, most of the surrounding population's sewage is directly discharged into this lagoon-environment without any treatment. ${ }^{4}$ Despite the activities with polluting potential in the Mundaú lagoon, studies involving systematic environmental monitoring of pollutants in this critical ecosystem are still scarce. 
The studies of Costa et al..$^{5}$ and Araujo et al. ${ }^{6}$ have, respectively, evaluated the levels of sterols and lipids in MMELC waters and sediments. Nevertheless, studies on the concentration of inorganic pollutants are still limited. MMELC is an estuary with a massive nutrient subsidy, a highly productive system where organisms are developed and serve as food and a source of income for the local population. However, this activity has presented problems due to anthropic impacts on the environment since it influences the alteration of this estuary's chemical constitution. ${ }^{7}$ In this system, bivalve mollusks, which are extensively consumed and commercialized, are the principal source of income, especially Mytella charruana. ${ }^{8}$ Bivalves are filtering, sessile organisms, which are easy to harvest. They are widely distributed, have a high oxygen availability tolerance, and their quality as an end product is of interest to public health. Thus, this set of factors contributes to the use of bivalve mollusks as (bio)indicators of environmental pollution, becoming an excellent indicator system of contamination by potentially toxic species.

Over time, chemical elements have become multipurpose, and some of them can be associated with domestic and industrial waste. Such elements are usually discharged into the environment without any prior treatment, absorbed by plants and animals, causing contamination/ intoxications along the food chain. ${ }^{9}$ Due to the toxic potential of some elements that can harm humans, when monitoring environmental areas, determinations to assess contamination levels are necessary. ${ }^{10}$ Thus, a way to monitor an environment's passive contamination is by determining inorganic contaminants, which can present toxicity to human beings when above the current legislation's levels.
In the present study, differing analytical strategies were applied to quantify potentially toxic elements (Al, As, Bi, $\mathrm{Cd}, \mathrm{Cr}, \mathrm{Cu}, \mathrm{Fe}, \mathrm{Hg}, \mathrm{Li}, \mathrm{Mn}, \mathrm{Mo}, \mathrm{Ni}, \mathrm{Pb}, \mathrm{Sb}, \mathrm{Sn}, \mathrm{V}$, and Zn) in Mundaú lagoon estuarine water samples between June 2017 and April 2019, this, together with mercury levels in sururu to assess the impact of environmental contamination on this system. Further, it was possible to establish the relationships between the concentrations of potentially toxic elements and the different sampling points' chemical identity using different chemometric strategies.

\section{Experimental}

Study area, water sampling, and the bivalve mollusk (Mytella charruana)

The focus of this study was the Mundaú-Manguaba lagoon estuary complex (MMELC) (Figure 1) in the municipality of Maceió (Alagoas, Brazil). The study area is already recognized for being productive, especially for the bivalve Mytella charruana (sururu), which serves as a source of income and food. According to the National Environment Council (CONAMA, resolution No. 357/2005), ${ }^{11}$ the water in this estuary is brackish (class 1) and is used by the population for recreation, aquaculture, fishing, animal husbandry, and agriculture.

The MMLEC estuary complex presents an average temperature of $25^{\circ} \mathrm{C}$, yet there is no defined rainy season, a marked variation in rainfall was recorded during the sampling period. In this study, seven surface water sampling campaigns, from June 2017 through April 2019, were carried out (Table S1, Supplementary Information (SI)

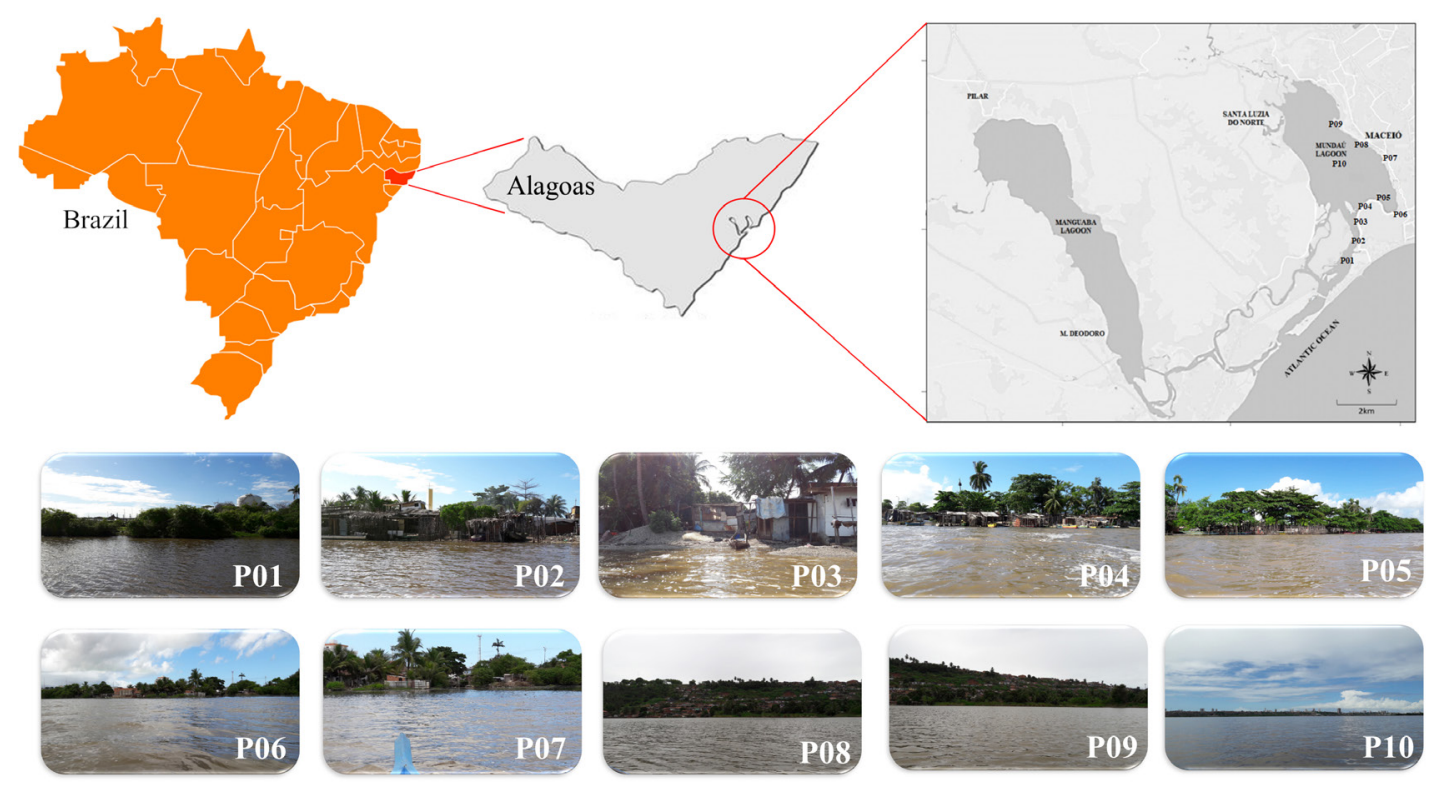

Figure 1. Sampling points (water and bivalve) in Mundaú lagoon (Alagoas, AL) between 2017 and 2019. P: sampling point. 
section). Samples (of up to $30 \mathrm{~cm}$ deep) in 10 different locations were taken ( $\mathrm{n}=70$ samples) considering the sampling criteria of proximity to industry, high/low population occupation, sururu harvesting sites, and sewage release (Table S2, SI section). The water samples (about $500 \mathrm{~mL}$ ) after collection were stored in amber glass and polyethylene vials, acidified with $\mathrm{HNO}_{3}(2.5 \% \mathrm{v} / \mathrm{v})$, filtered with a cellulose membrane $(0.45 \mu \mathrm{m})$, and kept under refrigeration at $4{ }^{\circ} \mathrm{C}$ until analysis.

Due to the intense rains in 2017, which made it impossible to harvest the Mytella charruana mollusk, sampling occurred in only four campaigns (from April 2018 to April 2019). The samples after collected were washed, the soft tissue was removed, and lyophilized (Terroni LS300, São Carlos, Brazil). They were then crushed in a knife mill and digested using a closed system in a microwave oven.

\section{Reagents and solutions}

All reagents used in the procedures were of analytical grade and acquired through Merck (Darmstadt, Germany), Sigma-Aldrich (St. Louis, USA), and Vetec (Rio de Janeiro Brazil): hydrochloric acid, nitric acid, hydrogen peroxide, sodium borohydride, sodium hydroxide, stannous chloride, potassium bromide, potassium bromate, potassium iodide, ascorbic acid, potassium biftalate, phenolphthalein, silver nitrate, and thiocyanate of potassium. All solutions were prepared in ultrapure water obtained from a Gehaka system (São Paulo, Brazil) with $18.2 \mathrm{M} \Omega \mathrm{cm}$ (at $25^{\circ} \mathrm{C}$ ). Before use, all working materials were previously washed with $\mathrm{HNO}_{3} 10 \%(\mathrm{v} / \mathrm{v})$ and ultrapure water. A reducing solution of $\mathrm{NaBH}_{4} 0.7 \%(\mathrm{~m} / \mathrm{v})$ was prepared by directly solubilizing $3.50 \mathrm{~g}$ of the reducing agent with $2 \mathrm{~g}$ of $\mathrm{NaOH}$ in $500 \mathrm{~mL}$ of ultrapure water. To prepare the $\mathrm{SnCl}_{2} 2 \%(\mathrm{~m} / \mathrm{v})$ solution, $10 \mathrm{~g}$ of the salt in $\mathrm{HCl} 0.5 \mathrm{M}(500 \mathrm{~mL})$ was used. The $\mathrm{KBr}$ (200 mM), $\mathrm{KBrO}_{3}(33 \mathrm{mM}), \mathrm{KI}(50 \% \mathrm{~m} / \mathrm{v})$, and ascorbic acid $12 \%(\mathrm{~m} / \mathrm{v})$ solutions were prepared in ultrapure water by directly weighing the salts. All solutions were prepared daily before analysis.

\section{Water sample analysis of potentially toxic elements}

The total concentrations of $\mathrm{Hg}$, As, $\mathrm{Se}$, and $\mathrm{Sb}$ in the MMELC water samples were determined using cold vapor atomic fluorescence spectrometry (or hydride generation) (HG/CV AFS) (PS Analytical, model 10.025 Millennium Merlin and model 10.055 Millennium Excalibur, UK), as detailed in the experimental conditions (Table S3, SI section).

The total concentrations of $\mathrm{Al}, \mathrm{Fe}, \mathrm{Cu}, \mathrm{Mn}, \mathrm{Sn}, \mathrm{Bi}, \mathrm{Li}$, $\mathrm{Mo}, \mathrm{Ni}$, and $\mathrm{V}$ in the water samples were determined using inductively coupled plasma mass spectrometry (ICP-MS), (Agilent Technologies series 7700, Japan). The integration time was $0.3 \mathrm{~s}$ per mass, having a plasma power of $1550 \mathrm{~W}$,

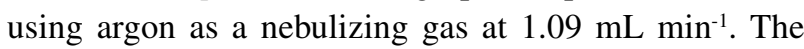
analytical curves were built from 1 to $100 \mu \mathrm{g} \mathrm{L}^{-1}$ for the elements with correlation coefficient $(r) \geq 0.990$, indicating good linearity of the curves in these ranges. The standards solutions were prepared in $\mathrm{HNO}_{3} 1.0 \%(\mathrm{v} / \mathrm{v})$, and salinity was compatibilized with the samples (estuarine water) using $\mathrm{NaCl}$.

The total concentrations of $\mathrm{Pb}, \mathrm{Cd}$, and $\mathrm{Zn}$ were determined by dissolution chronopotentiometry in the Nernst equilibrium in the absence of gradients (AGNES), using a $\mu$-autolab type III potentiostat/ galvanostat (Metrohm, model IME 663, Switzerland). The quantifications of the elements were obtained under different half-wave potentials $\left(E_{d}\right)$ and deposition times $\left(\mathrm{t}_{\mathrm{d}}\right): \mathrm{Pb}^{\mathrm{II}}: \mathrm{t}_{\mathrm{d}}=240 \mathrm{~s}$ and $\mathrm{E}_{\mathrm{d}}=-0.46 \mathrm{~V} ; \mathrm{Cd}^{\mathrm{II}}: \mathrm{t}_{\mathrm{d}}=300 \mathrm{~s}$ and $\mathrm{E}_{\mathrm{d}}=-0.655 \mathrm{~V}$; and $\mathrm{Zn}^{\mathrm{II}}: \mathrm{t}_{\mathrm{d}}=540 \mathrm{~s}, \mathrm{E}_{\mathrm{d}}=-1.1 \mathrm{~V}$, $I_{s}$ (stripping current) $=2 \mu \mathrm{A}$. The electrode rotation was $1000 \mathrm{rpm}$, and measurements were performed using $10 \mathrm{~mL}$ of each sample in the electrochemical cell, acidified with $\mathrm{HNO}_{3} 0.1 \mathrm{~mol} \mathrm{~L}^{-1}$. The concentration of metals was calculated from the relationship between AGNES redissolution time and a proportionality constant (h) from each analytical curve's linear regression. ${ }^{12}$

The determination of total chloride was performed using the Mohr method and making the reference solutions compatible with the matrix when necessary.

\section{Analysis of the Mytella charruana (sururu) samples}

According to the parameters already indicated, the total Hg concentration in the Mytella charruana samples was determined using the CV AFS technique (Table S3). The mollusk sample was prepared according to the procedure described by Araújo et al..$^{13}$ using microwave digestion (Milestone, Ethos One, Sorisole, Italy) (Table S4, SI section). Finally, the residual acidity was determined using a procedure acid-base titration of the digested blanks to make a compatible analytical curve.

\section{Statistical analysis}

All results are expressed in terms of mean \pm SD (standard deviation) for triplicate measurements $(n=3)$. The simple Student $t$-test at a $95 \%$ confidence level was applied to validate the methods. Spearman's correlation analysis at a 95\% confidence interval $(p<0.05)$ was used to assess the relationship between variables after application of the Shapiro-Wilk test (normality assessment). 
Principal component analysis (PCA) was performed to establish the main similarities and differences between the variables (concentration of potentially toxic elements) and the Mundaú lagoon sampling points, inserting the variables in the lines $\left(\mathrm{n}_{\text {lines }}=10\right)$ and the responses as colums ( $\left.\mathrm{n}_{\text {columns }}=126\right)$. The values were autoscaled using the difference between each point's measured value and the general average value and normalized by the global standard deviation. This strategy was applied due to the differences in the magnitude of the elemental concentrations. Finally, the Statistica 7.0 (StatSoft, USA) ${ }^{14}$ chemometric package was used for principal component analysis (PCA) calculations.

\section{Environmental contamination indicator}

The water pollution index (WPI), ${ }^{15}$ as indicated to assess water quality, was calculated as follows:

$\mathrm{WPI}=\sum_{n-1}^{n} \frac{\mathrm{A}_{\mathrm{i}}}{\mathrm{T}} \times \frac{1}{n}$

where $A_{i}$ is the concentration obtained for each element, $\mathrm{T}$ is the maximum concentration allowed by Brazilian legislation (CONAMA resolution No. 357/2005), ${ }^{11}$ and $n$ is the number of parameters measured. For WPI $\leq 0.3$, the water is considered very pure, WPI in the range 0.3-1.0 the water is considered pure, WPI in the range $1.0-2.0$ is considered moderately polluted, WPI in the range $2.0-4.0$ is considered polluted, WPI in the range 4.0-6.0 is considered impure and, and finally when WPI $>6.0$ the water is considered very impure-polluted. ${ }^{16}$

\section{Results and Discussion}

Validation of analytical procedures for water samples

Verification of the atomic fluorescence technique's selectivity for $\mathrm{Hg}$, As, $\mathrm{Se}$, and $\mathrm{Sb}$ quantification was performed for possible interferences $(\mathrm{Cd}, \mathrm{Pb}, \mathrm{Zn}, \mathrm{Mn}$,
$\mathrm{Cu}, \mathrm{Ni}, \mathrm{Al}, \mathrm{Mo}, \mathrm{Fe}$, and $\mathrm{Mg}$ ) in the saline water samples. No variation in sensitivity was observed in the presence of the species evaluated using the procedure described (Table S5, SI section). Additionally, an analyte recovery assay was applied for all techniques, with recoveries of 82 to $115 \%$; thus, it was possible to infer an absence of matrix effects. The main figures of merit of the applied methods are presented in Tables S3 and S6 (SI section).

\section{Evaluation of $\mathrm{pH}$ and chloride concentration}

According to CONAMA resolution, No. 357/2005, the $\mathrm{pH}$ value for brackish water (class 1) must be between 6.5 and 8.5. In the analyzed water samples (Figure 2a), the $\mathrm{pH}$ ranged from 6.72 (P01-S7) to 9.39 (P09-S6), and for most of the points ( $84 \%$ ) evaluated, the medium was basic; possibly due to the presence of ions such as $\mathrm{HCO}_{3}{ }^{-} / \mathrm{CO}_{3}{ }^{2-}$, phosphates, and others which act as weak bases in aqueous media. ${ }^{17}$ The $\mathrm{pH}$ variations could be attributed to the influence of ocean-rainwater communication (Table S1) with the pollution sources, such as domestic sewage, which can modify the ionic hydrogen concentration of the medium. When necessary, the water samples' total chloride concentration was evaluated to make the experimental conditions compatible with the different techniques. Six samples were evaluated (P01, P06, and $\mathrm{P} 10$ ) in two different sampling campaigns ( $\mathrm{S} 1$ and S3), considering the pluviometric index and proximity to the ocean. The total concentration of chloride ions varied from 1.95 to $3.09 \mathrm{~g} \mathrm{~L}^{-1}$ (Figure 2b). As a result of the reduction in the freshwater flow, periods of lower rainfall allow entry of more significant saltwater volumes, influenced by the tides. In periods with more rainfall, freshwater runoff is higher, leaving surface waters less saline. ${ }^{18}$

Determination of potentially toxic elements in water samples

Surface water samples were collected in seven sampling campaigns (June/2017 to April/2019) at 10 different

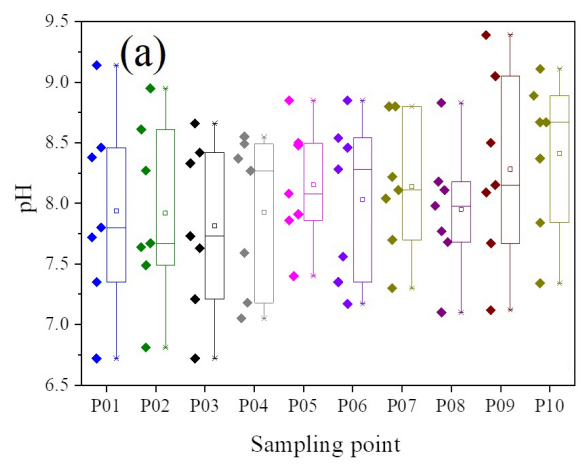

Figure 2. (a) Box plot of hydrogen potential (pH) and (b) total chloride concentration at different sampling points in the Mundaú lagoon (Maceió, AL). 
points totaling 70 samples analyzed for each element. The concentrations obtained for the elements As, Cd, Cr, Li, $\mathrm{Ni}, \mathrm{Se}$, and V were lower than the legislation's maximum allowed (Table 1 and Figure S1, SI section). This result indicated that anthropic activity discharges in the Mundaú lagoon did not influence the dynamics or elevation of these elements' concentrations in the environment.

Table 1. The maximum concentration allowed by the current legislation and concentration range of species quantified in a water sample from Mundaú Lagoon (Maceió, AL)

\begin{tabular}{|c|c|c|c|}
\hline Element & CONAMA $^{\mathrm{a}}$ & CONAMA $^{\mathrm{b}}$ & $\operatorname{Mean}^{c} \pm \mathrm{SD}(\min -\max ) /\left(\mu \mathrm{g} \mathrm{L}^{-1}\right)$ \\
\hline $\mathrm{Al}$ & 100 & 200 & $380 \pm 327(24.4-2008)$ \\
\hline As & 10 & 33 & $0.74 \pm 0.51(0.080-1.86)$ \\
\hline $\mathrm{Bi}$ & - & - & $81.9 \pm 51.3(18.4-1265)$ \\
\hline $\mathrm{Cd}$ & 5 & 10 & $<5.0$ \\
\hline $\mathrm{Cr}$ & 50 & - & $3.02 \pm 1.47(0.28-9.12)$ \\
\hline $\mathrm{Cu}$ & 5 & 13 & $3.23 \pm 1.06(1.88-13.0)$ \\
\hline $\mathrm{Fe}$ & 300 & 5000 & $820 \pm 646(84.9-4107)$ \\
\hline $\mathrm{Hg}$ & 0.2 & 0.2 & $0.33 \pm 0.31(<0.0069-2.92)$ \\
\hline $\mathrm{Li}$ & - & 2500 & $18.1 \pm 13.4(0.37-66.1)$ \\
\hline $\mathrm{Mn}$ & 100 & 500 & $66.1 \pm 28.4(10.7-200)$ \\
\hline Mo & - & - & $2.87 \pm 1.52(0.50-5.29)$ \\
\hline $\mathrm{Ni}$ & 25 & - & $0.84 \pm 0.67(<0.01-6.53)$ \\
\hline $\mathrm{Pb}$ & 10 & 33 & $779 \pm 319(192-1443)$ \\
\hline $\mathrm{Sb}$ & - & 5 & $0.65 \pm 0.61(<0.056-5.0)$ \\
\hline $\mathrm{Se}$ & 10 & 50 & $0.55 \pm 0.37(<0.04-1.50)$ \\
\hline $\mathrm{Sn}$ & - & - & $20.6 \pm 20.1(0.44-257)$ \\
\hline $\mathrm{V}$ & - & 100 & $4.72 \pm 1.16(2.36-8.96)$ \\
\hline $\mathrm{Zn}$ & 90 & 5000 & $557 \pm 190(121-997)$ \\
\hline
\end{tabular}

a,b National Environment Council (CONAMA) for brackish water (class 1) and freshwater (class 3), respectively; 'results of the present work. SD: standard deviation.

Since maximum allowable concentrations have not yet been established by current national legislation, for Bi $\left(18.4 \pm 4.8\right.$ to $\left.1265 \pm 26 \mu \mathrm{g} \mathrm{L}^{-1}\right)$, Mo $(0.50 \pm 0.04$ to $\left.5.29 \pm 0.30 \mu \mathrm{g} \mathrm{L}^{-1}\right)$ or $\mathrm{Sn}\left(0.44 \pm 0.07\right.$ to $\left.257 \pm 14 \mu \mathrm{g} \mathrm{L}^{-1}\right)$, it was not possible to measure impacts on human health of the total (unspecified) concentrations found (Figure S1, SI section). Bismuth can be found as a by-product of lead mining, so in some cases, sources of $\mathrm{Bi}$ contamination may be related to the presence of objects and systems containing $\mathrm{Pb}$. However, this does not occur with high frequency, considering that both elements are present in several different by-products. ${ }^{18-20}$ Lead-free Bi can be found in drugs recommended for diarrhea, indigestion, Helicobacter pylori treatment, stomach pains, for example, in addition to being used in sodas, the manufacture of cosmetics, and some metal alloys. Yu et al. ${ }^{21}$ determined $\mathrm{Bi}$ in river and lake water samples, which varied between 1.0 to $1.9 \mathrm{ng} \mathrm{\textrm {L } ^ { - 1 }}$. Madrakian et al..$^{22}$ and Snigur et al..$^{23}$ did not carry out the Bi determination because the concentrations were below the limit of detection $\left(0.3 \mathrm{ng} \mathrm{L}^{-1}\right)$. Thus, the values herein obtained for $\mathrm{Bi}$ can be considered high, and this element may also be useful as an indicator of environmental contamination. Mo is an essential element, but if consumed in high concentrations, it can lead to heart failure and gastroenterological disorders. It is found in food supplements, toy paints, and cleaning products, but its use increases alloy durability and corrosion. ${ }^{24}$ Santos et al. ${ }^{25}$ determined Mo in saline waters from Bahia (Brazil), obtaining values from 7.0 to $8.4 \mu \mathrm{g} \mathrm{L}^{-1}$, close to the values found for water samples from Mundaú lagoon (Maceió, $\mathrm{AL})$. According to the Brazilian national legislation, the maximum permitted concentration of tributyltin in brackish waters (class 1) is $0.010 \mu \mathrm{g} \mathrm{L}^{-1}$ (CONAMA Resolution No. 357/2005). ${ }^{11}$ Since this compound is an endocrine disruptor, it impairs reproductive functions and sexual development in aquatic organisms. ${ }^{26}$ However, for total $\mathrm{Sn}$, there is no set reference value (Figure S1). Sn is usually found in canned foods; it interferes with human zinc metabolism in high concentrations. ${ }^{27}$ Biata et al. ${ }^{28}$ and Mortazavi and Farmany ${ }^{29}$ quantified total $\mathrm{Sn}$ in the river (Soweto-Johannesburg, South Africa) and bottled water, obtaining respective concentrations of 1.51 and $5.23 \mu \mathrm{g} \mathrm{L}^{-1}$, which are lower than reported in this study.

Antimony can cause lung cancer, lesions in the central nervous system, and hemolysis. In contrast, it is used to produce drugs treating leishmaniasis. ${ }^{30}$ In the present study, a maximum $\mathrm{Sb}$ concentration was $5.0 \mu \mathrm{g} \mathrm{L}^{-1}$ (total), equivalent to the limit established by Brazilian legislation for freshwater (class 1) (Figure S1). There is no Sb value designated for brackish water, and therefore it could be classified as an emerging contaminant. Biata et al. ${ }^{28}$ and El-Sharjawy and $\mathrm{Amin}^{30}$ quantified total $\mathrm{Sb}$ in natural water samples (Soweto, Johannesburg, South Africa), where they obtained maximum concentrations from 22.1 and $4.70 \mu \mathrm{g} \mathrm{L}^{-1}$, respectively, reinforcing the concern associated with this element.

The total concentrations of $\mathrm{Al}, \mathrm{Cu}, \mathrm{Fe}, \mathrm{Hg}, \mathrm{Mn}, \mathrm{Pb}$, and $\mathrm{Zn}$ were above the environmental limits allowed by Brazilian legislation (Figure 3), indicating contamination. The variations in the concentrations encountered in the different sampling periods are justified by pluviometric variations and differing tides, population densities, and leaching of contaminants through runoff to the lagoon system. In general, individual elements (Figure S1) presented higher concentrations starting with P07, which is located in the upper estuary and characterized as having less tidal influence, and thus fewer dilutions of the elements analyzed. ${ }^{31}$ 

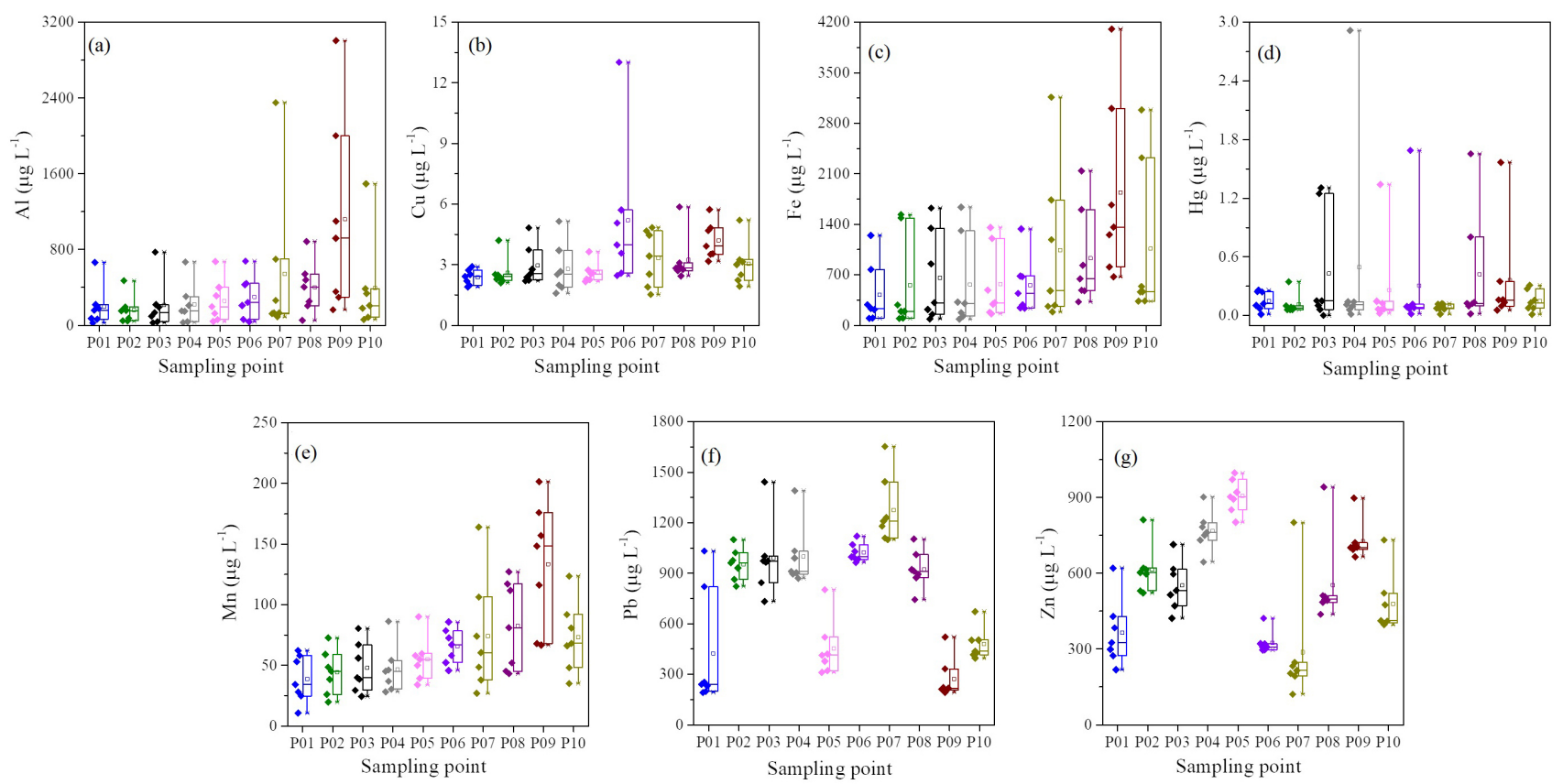

Figure 3. Box plot of the total concentration of (a) $\mathrm{Al}$, (b) $\mathrm{Cu}$, (c) $\mathrm{Fe}$, (d) $\mathrm{Hg}$, (e) $\mathrm{Mn}$, (f) $\mathrm{Pb}$, and (g) $\mathrm{Zn}$ in the estuarine water samples from the Mundaú lagoon (Maceió, $\mathrm{AL})(\mathrm{n}=3)$. Maximum concentration allowed by national legislation, CONAMA ( $\left.\mu \mathrm{g} \mathrm{L} \mathrm{L}^{-1}\right)$ : $\mathrm{Al}(100), \mathrm{Cu}(5), \mathrm{Fe}(300), \mathrm{Hg}(0.2), \mathrm{Mn}(100)$, $\mathrm{Pb}(10)$, and $\mathrm{Zn}(90)$.

Concentrations of $\mathrm{Al}$ ranged from 24.4 to $2008 \mu \mathrm{g} \mathrm{L}^{-1}$ (Figure 3a). Al is commonly used in packaging in the food industry, water, kitchen utensils, and pharmaceutical products. Also, $\mathrm{Al}$ salts are used in water treatment and as a food additive. High concentrations of $\mathrm{Al}$ in the human body can cause neurological and bone problems..$^{32}$ Therefore, environmental monitoring is essential for this element. Abdolmohammad-Zadeh and Rahimpour ${ }^{33}$ quantified $\mathrm{Al}$ in river water in Iran, obtaining a maximum value of $33.18 \mu \mathrm{g} \mathrm{L}^{-1}$, while Panhwara et al. ${ }^{34}$ found $10.2 \mu \mathrm{g} \mathrm{L}^{-1}$ in groundwater in Saudi Arabia.

The concentrations of $\mathrm{Cu}$ ranged from 1.88 to $13.03 \mu \mathrm{g} \mathrm{L}{ }^{-1}$, in this work, concentrations of approximately 2.5 times higher than allowed by Brazilian legislation were obtained (Figure 3b). In low concentrations, ionic $\mathrm{Cu}$ is a nutrient and is commonly found in food and environmental samples. However, it can present toxic effects in the organism in high concentrations. ${ }^{35}$ Mohammad et al..$^{36}$ and Bernalte et al.$^{37}$ in river waters in Iran and Colombia determined total $\mathrm{Cu}$ values of 7.90 and $12.2 \mu \mathrm{g} \mathrm{L}{ }^{-1}$, which are close to our study in estuarine water samples.

Iron concentrations ranged from 84.9 to $4107 \mu \mathrm{g} \mathrm{L}^{-1}$ (Figure 3c). Iron presents excellent bioavailability and biological importance as a micronutrient in many physiological functions. ${ }^{38}$ Thus, in well in the USA and river water in Egypt samples, respective values of 301 and $730 \mu \mathrm{g} \mathrm{L}^{-1}$ have been reported by Rohanifar et al. ${ }^{39}$ and Mohamed and Shalaby. ${ }^{40}$
Worldwide, mercury is one of the most toxic metals, and due to its presence in food and the environment, it is a global pollutant. ${ }^{41}$ Intoxication in humans can cause brain, stomach, heart, and kidney disease..$^{42}$ In this work, the measured $\mathrm{Hg}$ concentrations ranged from $<0.0069$ to $2.92 \mu \mathrm{g} \mathrm{L} \mathrm{L}^{-1}$ (Figure $3 \mathrm{~d}$ ), the maximum concentrations obtained were up to 14.2 times greater than allowed by the national legislation. Bernalte et al. ${ }^{37}$ determined total $\mathrm{Hg}$ in water samples from the Amazon river; the maximum value found was $6.7 \mu \mathrm{g} \mathrm{L}{ }^{-1}$. Lacerda et al. ${ }^{43}$ quantified $\mathrm{Hg}$ in estuarine water, obtaining concentrations in the range of 0.0084 to $0.012 \mu \mathrm{g} \mathrm{L}^{-1}$.

Associated with several biochemical processes in living organisms, $\mathrm{Mn}$ is an essential micronutrient, but at a high-level, it is also carcinogenic and genotoxic. ${ }^{44}$ The measured Mn concentrations ranged from 10.65 to $200.5 \mu \mathrm{g} \mathrm{L}^{-1}$ (Figure 3e). Mohammadi et al. ${ }^{45}$ quantified $\mathrm{Mn}$ in groundwater and river water samples in Iran, obtaining respective measurements of 19.3 and $16.2 \mu \mathrm{g} \mathrm{L}^{-1}$. Gomes et al. ${ }^{46}$ has reported concentrations of 128 to $264 \mu \mathrm{g} \mathrm{L}^{-1}$ in varied river waters in the city of Mariana (Minas Gerais, Brazil).

Lead can be found in paints, batteries, electronics, pesticides, plastics, and ceramics. Lead contamination can harm the nervous system, kidneys, and hematopoietic organs and contribute to cancer. ${ }^{47}$ In this work, the $\mathrm{Pb}$ level ranged from 192 to $1443 \mu \mathrm{g} \mathrm{L}^{-1}$ (Figure 3f), concentrations between 19 and 144 times greater than allowed by the national legislation. Kamel et $a l .^{48}$ determined $\mathrm{Pb}$ in 
river water samples $\left(26 \mu \mathrm{g} \mathrm{L}^{-1}\right)$ of the Nile River, while Zhao et al..$^{49}$ determined $\mathrm{Pb}$ in the lake and Yangtze River water in China from 526 to $718 \mathrm{ng} \mathrm{L}^{-1}$. Thus, we realized that the concentrations determined in the Mundaú lagoon are incredibly high concerning both the reference values and other studies, indicating the significant $\mathrm{Pb}$ contamination in this system.

Zinc is essential to various metabolic functions and a cofactor to several enzymes. The principal sources of contamination are food and water. High concentrations cause gastrointestinal disorders, diarrhea, and paralysis, among others. ${ }^{50}$ The measured $\mathrm{Zn}$ concentrations ranged from 121 to $997 \mu \mathrm{g} \mathrm{L}^{-1}$ (Figure $3 \mathrm{~g}$ ), therefore, 1.3 to 11 times greater than allowed by the national legislation. Pandey et al. ${ }^{51}$ quantified $\mathrm{Zn}$ in river water (South Korea) ranging from 100 to $550 \mu \mathrm{g} \mathrm{L}^{-1}$, while Schnack et al. ${ }^{52}$ in estuary water in Urussanga (Santa Catarina, Brazil)

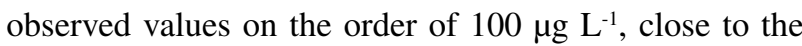
established limit.

\section{Correlation analysis}

Correlation analysis was used to relate the degree of dependence between variables, using total element concentration (Table S7, SI section). Initially, the Shapiro-Wilk test was applied to assess the data distribution, revealing that it was not normal for certain elements. Thus, Spearman correlation was used starting with the Al, As, Bi, $\mathrm{Cd}, \mathrm{Cr}, \mathrm{Cu}, \mathrm{Fe}, \mathrm{Hg}$, Li, Mn, Mo, Ni, Pb, Sb, Sn, V, and Zn concentrations at a confidence interval of $95 \%(p<0.05)$.

In this study, three groups were considered. The first were positively correlating data, possibly suggesting that these elements present a similar. In this group, significant positive correlations occurred for $\mathrm{Fe}, \mathrm{Al}, \mathrm{Mn}, \mathrm{Bi}$, and $\mathrm{Ni}$, where the correlation coefficient ranged from 0.606 to 0.840. The high corrections between $\mathrm{Fe} \times \mathrm{Al}, \mathrm{Fe} \times \mathrm{Bi}$, and $\mathrm{Fe} \times \mathrm{Mn}$ may be related to mining, cement residues, and domestic sewage. The positive correlations between Mo $\times$ Se and Mo $\times$ As are also noteworthy.

The second group was negatively correlating with the elements. Mo presented significant negative correlations with all the elements tested, emphasizing $\mathrm{Fe}$ and $\mathrm{Cr}$, except for the correlations with Se and As. Molybdenum is essential in vegetable metabolism, and the profile obtained may be related to aquatic plant bioremediation processes. Significant negative correlations that stood out were $\mathrm{Cr} \times \mathrm{As}, \mathrm{Sn} \times \mathrm{Se}$, and $\mathrm{Sn} \times \mathrm{As}$. Finally, the correlations constituting the third grouping were insignificant at a $95 \%$ confidence level $(p<0.05)$

\section{Principal component analysis (PCA)}

The scores and loadings graphs were used to discriminate the different groups formed considering the sampling points (Figure 4). Since the sampling was carried out at different times, the pluviometric index (PI) was used as a comparison criterion, and the profile was also evaluated using all the results. The total variance $(\mathrm{PC} 1+\mathrm{PC} 2)$ varied from $58.9 \%(\mathrm{PI}=30 \mathrm{~mm}, \mathrm{~S} 5)$ to $65.4 \%$ (PI $=306 \mathrm{~mm}, \mathrm{~S} 4)$, using data autoscaled to offset the effects of different ranges of values. Four groups were discriminated (G1-G4) with P01 (G1) and P09 (G4) always separated. This profile is justified because P01 is close to the industrial zone and the sea, while P09 suffers less influence of the tides away from the ocean and less population density (Figures 4a-4b). The G2 and G3 are
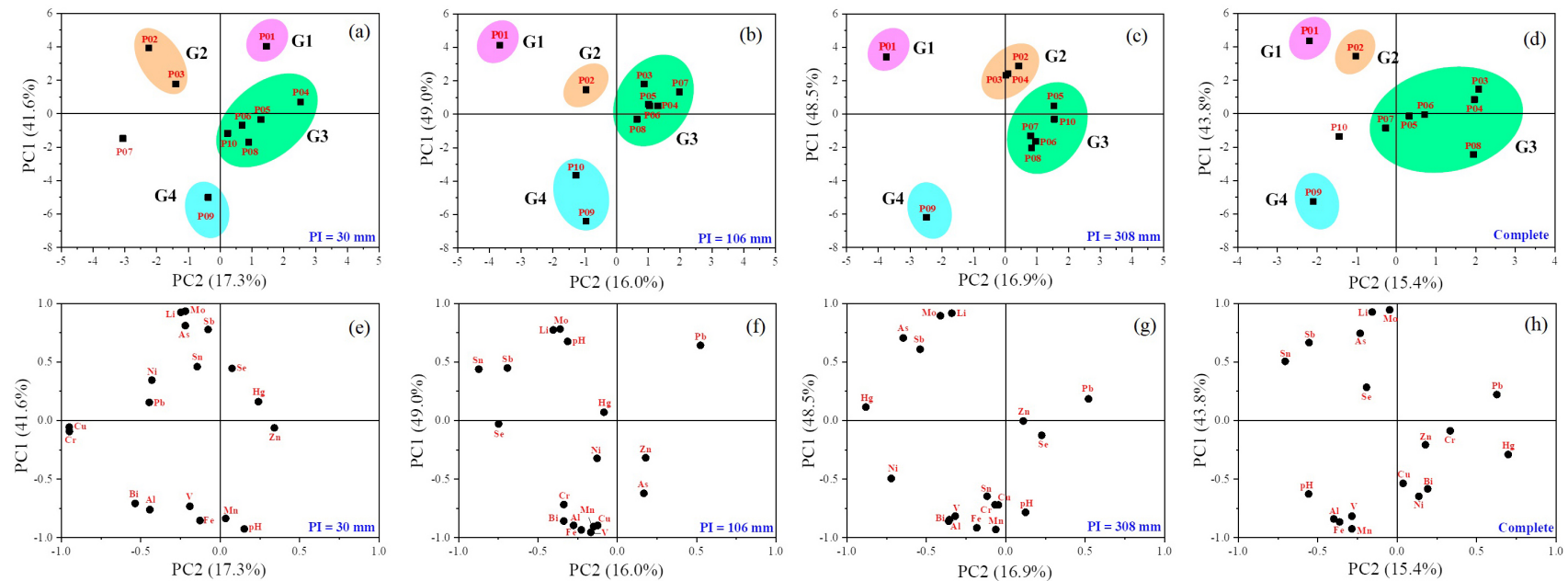

Figure 4. Scores and loadings scatter plot for PCA data of potentially toxic element concentrations (and pH) in water samples of Mundaú lagoon (Maceió, $\mathrm{AL}$ ) considering the pluviometric index (PI) based on sampling time and the complete data. Score plot: (a) PI $=30 \mathrm{~mm}(\mathrm{~S} 5)$, (b) PI = 106 $\mathrm{mm}$ (S2), (c) PI = $308 \mathrm{~mm}$ (S4) and (d) complete (all results). Loading plot: (e) PI = $30 \mathrm{~mm}$ (S5), (f) PI = $106 \mathrm{~mm}$ (S2), (g) PI = $308 \mathrm{~mm}$ (S4) and (h) complete (all results). 
formed by sampling sites with the highest domestic sewage discharge input and a high population occupation influence (PpI, Table S1) without basic sanitation (Figures 4c-4d). In general, regardless of climatic conditions (PI variation), the separation in the score graphs (Figures $4 a-4 c$ ) was similar when compared to the profile using the complete results (Figure 4d), showing that there is a chemical-defined identity concerning the sampling points.

Based on the loadings graphs (Figures $4 \mathrm{e}-4 \mathrm{~h}$ ), the groups' discrimination was influenced more effectively by $\mathrm{Li}, \mathrm{Sn}, \mathrm{Sb}, \mathrm{As}$, and Mo for $\mathrm{G} 1$ and $\mathrm{G} 2$. The elements $\mathrm{Pb}, \mathrm{Hg}$, and $\mathrm{Zn}$, influenced $\mathrm{G} 3$ resolution more significantly, while $\mathrm{Bi}, \mathrm{Al}, \mathrm{Fe}, \mathrm{Mn}, \mathrm{Cu}$, and $\mathrm{V}$ the $\mathrm{G} 4$. The elements related to the discrimination of groups $\mathrm{G} 1, \mathrm{G} 2$, and $\mathrm{G} 3$ are present in the water due to discharges of industrial effluents and urban sewage, residues of paints, lamps, and electronics. The elements associated with the G4 group may be due to the proximity to metallurgical and mining industries located near the Mundaú lagoon.

A relationship between elements based on the respective metal hydroxides' solubility was observed. It is noted that cations derived from the $\mathrm{Al}, \mathrm{Bi}, \mathrm{Fe}$, and $\mathrm{Mn}$, as well as $\mathrm{Cu}$ and $\mathrm{Cr}$, have similar molar solubility values, mainly justifying the discrimination of P09, the closest point to the mining area. Thus, the element concentration and the $\mathrm{pH}$ can determine the distribution and dynamics of the different species in the environment through acid-base and complex equilibrium. Finally, these elements have a high correlation, reinforcing the association between solubility and $\mathrm{pH}$.

\section{Water pollution index}

The estuarine water nature was assessed based on water pollution index (WPI) (Table 2). This parameter indicated that for P01 to P10 sampling points, the water quality as impure or strongly impure, using the concentration of $\mathrm{Hg}, \mathrm{Mn}, \mathrm{Al}, \mathrm{Fe}, \mathrm{Pb}, \mathrm{Zn}, \mathrm{Se}, \mathrm{As}, \mathrm{Cu}, \mathrm{Cr}$, and $\mathrm{Ni}$ during all sampling, since, for these elements, there are reference values in Brazilian legislation. ${ }^{11}$ The WPI values, in general, corroborate the results obtained considering the limits of the national legislation, since systematically for $\mathrm{Al}, \mathrm{Cu}$, $\mathrm{Fe}, \mathrm{Hg}, \mathrm{Mn}, \mathrm{Pb}$, and $\mathrm{Zn}$, the concentrations are above the maximum established. The WPI values are related to the various anthropic activities suffered in Mundaú Lagoon's region (Maceió, $\mathrm{AL}$ ), from the domestic sewage released without treatment, fertilizer, and agrochemical residues used in the crops around the lagoon.

Brankov et al.,$^{53}$ using WPI values, evaluated the water from the Timok river basin (Serbia), and through their results, classified the water as polluted. Armid et al. ${ }^{16}$
Table 2. Water pollution index (WPI) $\mathrm{Hg}, \mathrm{Mn}, \mathrm{Al}, \mathrm{Fe}, \mathrm{Pb}, \mathrm{Zn}, \mathrm{Se}, \mathrm{As}$, $\mathrm{Cu}, \mathrm{Cr}$, and Ni quantified in the Mundaú lagoon (Maceió, AL). The WPI was calculated considering the elements that present reference values for the type of water analyzed

\begin{tabular}{lcc}
\hline Sampling point & WPI & Classification \\
\hline P01 & 4.69 & impure \\
P02 & 9.75 & strongly impure \\
P03 & 10.27 & strongly impure \\
P04 & 10.55 & strongly impure \\
P05 & 5.65 & impure \\
P06 & 10.37 & strongly impure \\
P07 & 12.86 & strongly impure \\
P08 & 9.93 & strongly impure \\
P09 & 5.15 & impure \\
P10 & 5.72 & impure \\
\hline
\end{tabular}

assessed the contamination of $\mathrm{Pb}, \mathrm{Cu}, \mathrm{As}, \mathrm{Fe}$, and $\mathrm{Ni}$ in seawater (Staring Bay, Indonesia), and based on WPI values, the water was considered practically pure, the opposite profile observed in the current work.

For Brazilian aquatic environments, WPI values were calculated based on information from each system. Ferreira et $a l . .^{54}$ evaluated the water of urban rivers of the metropolitan region of Manaus (Rio Negro and Solimões) quantified $\mathrm{Cr}, \mathrm{Cu}, \mathrm{Mn}, \mathrm{Ni}$, and $\mathrm{Zn}$ in the rainy and dry season; the water was classified as pure (WPI equal to 0.64 ) and strongly impure (WPI equal to 60), respectively. Alves et al. ${ }^{55}$ quantified $\mathrm{As}, \mathrm{Be}, \mathrm{Cd}, \mathrm{Cr}, \mathrm{Cu}, \mathrm{Pb}, \mathrm{Mn}, \mathrm{Hg}$, $\mathrm{Ni}$, and $\mathrm{Zn}$ in the water of the Pardo River of Ribeirão Preto (São Paulo), both in the dry and rainy seasons, the values of WPI indicated that water is very pure (WPI equal to 1.17 and 1.16, respectively). A similar profile was obtained by Silva et al..$^{56}$ determined $\mathrm{Cd}, \mathrm{Co}, \mathrm{Pb}$, and $\mathrm{Ni}$ in the water of the river and Jequié lagoon (Bahia), obtaining WPI values below 0.3 , indicative of very pure water. In this way, the WPI values (4.69-12.86) obtained for the different points of the Mundaú lagoon reinforce that this aquatic environmental system presents contamination by different sources, effectively influencing the water quality.

\section{Determination of mercury in Mytella charruana (sururu)}

Sururu was obtained from the sampling carried out between 04/2018 to 04/2019 (Table S1). Nineteen samples were analyzed, $\mathrm{P} 09$ being the only point where the material was not collected. Due to environmental variability and intense fishing activity, bivalve (in all samples) was obtained only for P06. Since Hg contamination in humans usually occurs through eating seafood, only this element was evaluated in the bivalves..$^{41}$ The total $\mathrm{Hg}$ concentrations 
ranged from $0.036 \pm 0.005$ to $0.63 \pm 0.10 \mathrm{mg} \mathrm{kg}^{-1}$ in dry weight for P08 (SS4) and P02 (SS4), respectively (Table 3). The maximum concentration of $\mathrm{Hg}$ in wet weight was $0.14 \pm 0.08 \mathrm{mg} \mathrm{kg}^{-1}$ P02 (SS4). The ANVISA (2013) ${ }^{57}$ establishes a maximum limit for mercury of $0.5 \mathrm{mg} \mathrm{kg}^{-1}$ in mass for bivalves, considering how food is consumed. Sururu can be eaten cooked (wet weight) or as a meal (dry weight); this way, the results were expressed considering these possibilities. Thus, $95 \%$ of the analyzed samples presented a concentration below the maximum value in dry weight, while no sample exceeded the maximum in wet weight. According to Sharif et al. ${ }^{58}$ variations in $\mathrm{Hg}$ concentrations are justified: since mollusks present various bioaccumulation strategies associated with their eating habits and anthropogenic activities (when close to the collection site), by climatic changes and metabolic reactions, and by both anatomical (size and weight) and physiological differences.

For most of the results, the concentrations obtained were within the maximum limit allowed by the legislation. However, excessive consumption of sururu is a concern for human health since $\mathrm{Hg}$ accumulates in the body. Similar results were observed by Higino et al..$^{59}$ and Costa et al. ${ }^{60}$ who obtained concentrations above Brazilian recommendations in different bivalve mollusk species. Machado et al. ${ }^{61}$ and Pereira et al..$^{62}$ obtained concentrations below the legislation's maximum allowed. In samples similar to the current study, Santos et al. ${ }^{7}$ (a study in the same location as this work) found values of $\mathrm{Hg}<0.013 \mathrm{mg} \mathrm{kg}^{-1}$, which likely reveals an increase in $\mathrm{Hg}$ concentrations over the past few years.

\section{Conclusions}

Based on this study, water samples from the Mundaú lagoon (Maceió-AL) presented total concentrations of $\mathrm{Al}, \mathrm{Cu}, \mathrm{Fe}, \mathrm{Hg}, \mathrm{Mn}, \mathrm{Pb}$, and $\mathrm{Zn}$ above those allowed the current national legislation. According to the WPI values, it was verified that the studied environment has signs of contamination. The contamination may be associated with urbanization and unplanned occupation by the population, industries, and sewage discharge, damaging the environment and affecting the local population. Chemometric analyses indicated a distinct chemical character for each sampling point, with no discriminating trends. Therefore, the environmental monitoring performed indicated a potential for food (sururu) and water contamination if obtained in the region.

Table 3. Total Hg concentrations in sururu from Mundaú lagoon (Maceió, AL)

\begin{tabular}{|c|c|c|c|c|c|}
\hline \multirow{2}{*}{ Point $^{a}$} & \multirow{2}{*}{ Condition $^{\mathrm{b}}$} & \multicolumn{4}{|c|}{$\mathrm{Hg}$ concentration / $\left(\mathrm{mg} \mathrm{kg}^{-1}\right)$} \\
\hline & & $\mathrm{SS} 1^{\mathrm{c}}$ & SS2 & SS3 & SS4 \\
\hline \multirow{2}{*}{ P01 } & $\mathrm{D}$ & - & $0.34 \pm 0.05$ & - & - \\
\hline & $\mathrm{W}$ & - & $0.072 \pm 0.006$ & - & - \\
\hline \multirow{2}{*}{ P02 } & $\mathrm{D}$ & - & $0.40 \pm 0.06$ & - & $0.63 \pm 0.10$ \\
\hline & $\mathrm{W}$ & - & $0.086 \pm 0.005$ & - & $0.14 \pm 0.08$ \\
\hline \multirow{2}{*}{ P03 } & $\mathrm{D}$ & $0.43 \pm 0.05$ & $0.29 \pm 0.01$ & - & $0.39 \pm 0.08$ \\
\hline & $\mathrm{W}$ & $0.091 \pm 0.010$ & $0.063 \pm 0.005$ & & $0.085 \pm 0.009$ \\
\hline \multirow{2}{*}{ P04 } & $\mathrm{D}$ & - & - & - & $0.050 \pm 0.004$ \\
\hline & $\mathrm{W}$ & & - & - & $<$ LOD \\
\hline \multirow{2}{*}{ P05 } & $\mathrm{D}$ & - & $0.28 \pm 0.07$ & $0.17 \pm 0.01$ & $0.040 \pm 0.002$ \\
\hline & $\mathrm{W}$ & - & $0.066 \pm 0.007$ & $0.038 \pm 0.004$ & $<$ LOD \\
\hline \multirow{2}{*}{ P06 } & $\mathrm{D}$ & $0.26 \pm 0.03$ & $0.30 \pm 0.02$ & $0.082 \pm 0.011$ & $0.170 \pm 0.006$ \\
\hline & $\mathrm{W}$ & $0.057 \pm 0.005$ & $0.062 \pm 0.004$ & $0.023 \pm 0.003$ & $0.041 \pm 0.005$ \\
\hline \multirow{2}{*}{ P07 } & $\mathrm{D}$ & - & - & $0.090 \pm 0.010$ & $0.050 \pm 0.005$ \\
\hline & W & - & - & $0.025 \pm 0.003$ & $<$ LOD \\
\hline \multirow{2}{*}{ P08 } & $\mathrm{D}$ & - & - & - & $0.036 \pm 0.005$ \\
\hline & W & - & - & - & $<$ LOD \\
\hline \multirow{2}{*}{ P09 } & $\mathrm{D}$ & - & - & - & - \\
\hline & $\mathrm{W}$ & - & - & - & - \\
\hline \multirow{2}{*}{$\mathrm{P} 10$} & $\mathrm{D}$ & - & - & $0.18 \pm 0.10$ & $0.21 \pm 0.04$ \\
\hline & $\mathrm{W}$ & - & - & $0.041 \pm 0.004$ & $0.047 \pm 0.005$ \\
\hline
\end{tabular}

aP: sampling point; ${ }^{b}$ dry (D) and wet (W) weight; ' $S S$ : sururu sampling point. LOD: limit of detection. 


\section{Supplementary Information}

Supplementary information is available free of charge at http://jbcs.sbq.org.br as PDF file.

\section{Acknowledgments}

The authors thank Coordenação de Aperfeiçoamento de Pessoal de Nível Superior - Brazil (CAPES) - Finance Code 001, Conselho Nacional de Desenvolvimento Científico e Tecnológico (CNPq) for financial support and fellowships (JCCS and CCN), and Fundação de Amparo à Pesquisa do Estado de Alagoas (FAPEAL, process number: 60030 000863/2016).

\section{Author Contributions}

Mayara C. dos Santos was responsible for conceptualization, methodology, validation, investigation, formal analysis, and writing original draft; Reginaldo C. da Silva Filho for investigation and formal analysis; Ana Catarina R. Leite for investigation, formal analysis, and writing original draft; Clésia Cristina Nascentes for methodology, validation, investigation, formal analysis, and writing original draft; Wander Gustavo Botero for methodology, validation, investigation, formal analysis, and writing original draft; Josué C. C. Santos for conceptualization, funding acquisition, investigation, project administration, resources, and writing-review and editing.

\section{References}

1. Araújo, M. S. L. C.; Calado, T. C. S.; Revista de Gestão Costeira Integrada 2008, 8, 169, available at https://www.redalyc.org/ pdf/3883/388340124013.pdf, accessed in April 2021.

2. Ministério do Meio Ambiente, Agência Nacional de Águas (ANA); Plano de Ações e Gestão Integrada do Complexo Estuarino Lagunar Mundaú-Mangaba (CELMM): Resumo Executivo, 2006, available at http://arquivos.ana.gov.br/ institucional/sge/CEDOC/Catalogo/2006/CELMM.pdf, accessed in April 2021.

3. Silva, D. F.; Sousa, F. A. S.; Braz. J. Phys. Geogr. 2009, 1, 78.

4. https://www.ana.gov.br/noticias-antigas/pescadores-retirammais-de-20-caminhaues-de-lixo.2019-03-15.5970314558, accessed in April 2021.

5. Costa, T. L. F.; Araujo, M. P.; Carreira, R. S.; Quim. Nova 2010 , 33, 1915.

6. Araujo, M. P.; Costa, T. L. F.; Carreira, R. S.; Quim. Nova 2011, 34, 64 .

7. Santos, T. M. M.; Sawaya, A. L.; Silva, M. C. D.; Santos, A. F.; Neto, J. A. B.; Florêncio, T. M. M. T.; Demetra 2014, 9, 811.
8. Tamano, L. T. O.; Lima, B. B. C.; Silva, J.; Araujo, D. M.; Caminhos de Geografia 2020, 21, 306.

9. Mohn, W. W.; Martin, V. J. J. E.; Yu, Z. T.; Water Sci. Technol. 1999, 40, 273.

10. Campos, A. E. L.; Nunes, G. S.; Oliveira, J. C. S.; Toscano, I. A. S.; Quim. Nova 2009, 32, 960.

11. Conselho Nacional do Meio Ambiente (CONAMA); Resolução No. 357, Dispõe sobre A Classificação dos Corpos de Água e Diretrizes Ambientais para o seu Enquadramento, bem como Estabelece as Condições e Padrões de Lançamento de Efluentes, $e$ dá outras Providências; Diário Oficial da União (DOU), Brasília, No. 53, de 18/03/2005, p. 58, available at https://www. mma.gov. br/port/conama/res/res05/res35705.pdf, accessed in April 2021.

12. Janot, N.; Pinheiro, J. P.; Botero, W. G.; Meeussen, J. C. L.; Groenenberg, E.; Environ. Chem. 2016, 14, 31.

13. Araújo, G. C. L.; Gonzalez, M. H.; Ferreira, A. G.; Nogueira, A. R. A.; Nóbrega J. A.; Spectrochim. Acta, Part B 2002, 57, 2121.

14. Statistica, 7.0; StatSoft, USA, 2004.

15. Popović, N. Z.; Đuknić, J. A.; Atlagić, J. Ž. Č.; Raković, M. J.; Marinković, N. S.; Tubić, B. P.; Paunović, M. M.; Acta Zool. Bulg. 2016, 68, 97.

16. Armid, A.; Shinjo, R.; Takwir, A.; Rusland, R.; Wijaya, A. R.; J. Braz. Chem. Soc. 2021, 32, 299.

17. Schafer, A.; Fundamentos de Ecologia e Biogeografia das Águas Continentais; UFRGS-Federal University of Rio Grande do Sul: Porto Alegre, 1985.

18. Montes, M. J. F.; Paulo, J. G.; Filho, G. A. N.; Gaspar, F. L.; Feitosa, F. A.; Junior, A. C. S.; Batista, T. N. F.; Travassos, R. K.; Pitanga, M. E. J.; J. Coastal Res. 2011, 64, 1798.

19. Tighe, M.; Beidinger, H.; Knaub, C.; Sisk, M.; Peaslee, G. F.; Lierberman, M.; Chemosphere 2019, 235, 297.

20. Barache, U. B.; Shaikh, A. B.; Deodware, S. A.; Dhale, P. C.; Kamble, G. S.; Lokhande, T. N.; Gaikwad, S. H.; Groundwater Sustainable Dev. 2019, 9, 100221.

21. Yu, Y.; Zhao, Q.; Bao, H.; Mou, Q.; Shi, Z.; Chen, Y.; Gao, Y.; Geostand. Geoanal. Res. 2020, 44, 617.

22. Madrakian, T.; Afkhami, A.; Esmaeili, A.; Talanta 2003, 60, 831.

23. Snigur, D.; Chebotarev, A.; Dubovyiy, V.; Barbalat, D.; Bevziuk, K.; Microchem. J. 2018, 142, 273.

24. Hays, S. M.; Macey, K.; Poddalgoda, D.; Lu, M.; Nong, A.; Aylward, L. L.; Regul. Toxicol. Pharmacol. 2016, 77, 223.

25. Santos, H. C. M.; Korn, M. G. A.; Ferreira, S. L. C.; Anal. Chim. Acta 2001, 426, 78.

26. Amendola, L.; Cortese, M.; Vinatoru, D.; Sposato, S.; Insogna, S.; Anal. Chim. Acta 2017, 975, 70.

27. Ulusoy, S.; Ulusoy, H. I.; Akçay, M.; Gurkan, R.; Food Chem. 2012, 134, 419.

28. Biata, N. R.; Mashile, G. P.; Ramontja, J.; Mketo, N.; Nomngongo, P. N.; J. Food Compos. Anal. 2019, 76, 14. 
29. Mortazavi, S. S.; Farmany, A.; Iran. J. Sci. Technol., Trans. A. Sci. 2018, 42, 539.

30. El-Sharjawy, A. M.; Amin, A. S.; Anal. Biochem. 2016, 492, 1.

31. Miranda, L. B.; Castro, B. M.; Kjerfve, B.; Princípios de Oceanografia Física de Estuários, $2^{\text {nd }}$ ed.; Edusp: São Paulo, 2002.

32. Yildiz, E.; Saçmaci, S.; Saçmaci, M.; Ulgen, A.; Food Chem. 2017, 237, 942.

33. Abdolmohammad-Zadeh, H.; Rahimpour, E.; Anal. Chim. Acta 2015, 881, 54.

34. Panhwara, A. H.; Tuzena, M.; Kazib, T. G.; Talanta 2018, 178, 588.

35. Ozkantar, N.; Yilmaz, E.; Soylak, M.; Tuzen, M.; Food Chem. 2020, 321, 126737.

36. Mohammad, S. Z.; Shamspur, T.; Baghelani, Y. M.; Arabian J. Chem. 2014, 12, 1751.

37. Bernalte, E.; Arévalo, S.; Pérez-Taborda, J.; Wenk, J.; Estrela, P.; Avila, A.; Lorenzo, M. D.; Sens. Actuators, B 2020, 307, 127620 .

38. Waska, H.; Brumsack, H.; Massmann, G.; Koschinsky, A.; Schnetger, B.; Simon, H.; Dittmar, T.; Geochim. Cosmochim. Acta 2019, 259, 211.

39. Rohanifar, A.; Rodriguez, L. B. Devasurendra, A. M.; Alipourasiabi, N.; Anderson, J. L.; Andersond, J. R.; Talanta 2018, 188, 570 .

40. Mohamed, A. A.; Shalaby, A. A.; Food Chem. 2019, 274, 360.

41. Angyus, S. B.; Darvasi, E.; Ponta, M.; Petreus, D.; Etz, R.; Senila, M.; Frentiu, M.; Frenti, T.; Talanta 2020, 217, 121067.

42. Cui, J.; Dong, N.; Wang, M.; Jiang, Y.; Miao, P.; Part. Part. Syst. Charact. 2020, 37, 1900149.

43. Lacerda, L. D.; Soares, T. C. M.; Costa, B. G.; Godoy, M. D. P.; Bull. Environ. Contam. Toxicol. 2011, 87, 657.

44. Ahmed, M. J.; Islam, M. T.; Hossain, F.; RSC Adv. 2018, 8, 5509.

45. Mohammadi, S. Z.; Shamspur, T.; Baghelani, Y. M.; Arabian J. Chem. 2019, 12, 1751.

46. Gomes, L. C.; Chippari-Gomes, A. R.; Miranda, T. O.; Pereira, T. M.; Merçon, J.; Davel, V. C.; Barbosa, B. V.; Pereira, A. C. H.; Frossard, A.; Ramos, J. P. L.; Braz. J. Biol. 2018, 79, 659.
47. Cheng, J.; Li, Q.; Zhao, M.; Wang, Z.; Anal. Chim. Acta 2019 , 1077, 107.

48. Kamel, A. H.; Amr, A. E. E.; Al-Omar, M. A.; Elsayed, E.; Appl. Sci. 2019, 9, 4752.

49. Zhao, B.; He, M.; Chen, B.; Hu, B.; Microchim. Acta 2019, 186.

50. Furtado, L. A.; Lucena, Í, O.; Fernandes, J. O.; Lepri, F. G.; Martins, D. L.; Semaan, F. S.; Measurement 2018, 125, 651.

51. Pandey, L. K.; Park, J.; Son, D. H.; Kim, W.; Islam, M. S.; Choi, S.; Lee, H. Han, T.; Sci. Total Environ. 2019, 651, 323.

52. Schnack, C. S.; Menezes, C. T. B.; Ceni, G.; Munari, A. B.; Braz. J. Biosci. 2018, 16, 98.

53. Brankov, J.; Milijašević, D.; Milanović, A.; Arch. Environ. Prot. 2012, 38, 49.

54. Ferreira, M. S.; Fontes, M. P. F.; Pacheco, A. A.; Lima, H. N.; Santos, J. Z. L.; Sci. Total Environ. 2020, 709, 134471.

55. Alves, R. I. S.; Sampaio, C. F.; Nadal, M.; Schuhmacher, M.; Domingo, J. L.; Segura-Muñoz, S. I.; Environ. Res. 2014, 133, 149.

56. Silva, E. S.; Correia, L. O.; Santos, L. O.; Vieria, E. V. S.; Lemos, V. A.; Microchim. Acta 2012, 178, 269.

57. Agência Nacional de Vigilância Sanitária (ANVISA); Resolução No. 42, 29 de agosto de 2013, Dispõe sobre o Regulamento Técnico MERCOSUL sobre Limites Máximos de Contaminantes Inorgânicos em Alimentos; available at http://bvsms.saude.gov. br/bvs/saudelegis/anvisa/2013/rdc0042_29_08_2013.html, accessed in April 2021.

58. Sharif, R.; Chong, E.; Meng, C. K.; Malays. J. Nutr. 2016, 22, 301.

59. Higino, P. A. S.; Jesus, T. B.; Carvalho, C. E. V.; Tonial, L. S. S.; Calado, T. C. S.; Rev. Virtual Quim. 2012, 4, 393.

60. Costa, F. N.; Korn, M. G. A.; Brito, G. B.; Ferlin, S.; Fostier, A. H.; Food Chem. 2016, 192, 837.

61. Machado, I. C.; Maio, F. D.; Kira, C. S.; Carvalho, M. F. H.; Rev. Inst. Adolfo Lutz 2002, 61, 13.

62. Pereira, O. M.; Henriques, M. B.; Zenebon, O.; Sakuma, A.; Kira, C. S. Pereira, O. M.; Rev. Inst. Adolfo Lutz 2002, 61, 19.

Submitted: January 30, 2021

Published online: May 6, 2021 